\title{
О РОЛИ ЭВОЛЮЦИОНИЗМА В РАЗВИТИИ ЗНАНИЯ О ПСИХИЧЕСКОМ: НА СТЫКЕ ПСИХИАТРИИ, ПСИХОАНАЛИЗА, ПСИХОЛОГИИ И ФИЛОСОФИИ
}

\begin{abstract}
Аннотация. Позитивное знание в западной культуре сводится к приведению определенной области реальности в соответствие с представлениями о механизме или системе как о сложной иелостности, совокупности гомо- или гетерогенных элементов, объединенных отношениями определенного типа. Далее, эволюиия представлений о механизме (механизм - организм - структура -система) достаточно быстро приводит исследователей квыводу об эволюиии механизма. Таким образом, эпистемический инвариант включает в себя механицизм (в широком смысле этого слова), энергетизм и эволюичонизм. На примере трансдисииплинарной области психиатрии, психоанализа, психологии, неврологии и философии, которую автор именует «психофилософией», показано применение данного эпистемического варианта к исследованию области психического.

Ключевые слова: философия, эволюционизм, психофилософия, психиатрия, психоанализ, органодинамизм, механицизм, энергетизм, иизофрения, структура.
\end{abstract}

\section{Механицизм, эволюционизм, энергетизм в западном знании}

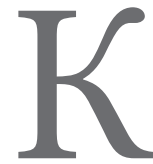
о второй половине ХХ в. в Западной культуре, главным образом во Франции, формируется традиция активного философского осмысления проблемы безумия с привлечением последних достижений психоанализа и психиатрии, сопровождающаяся революционными практиками психиатрической помощи (клиника La Bord), а также политизацией безумия (Ф. Гваттари, Ж. Делёз). Возникает отдельный жанр психофилософии, к которому сегодня можно причислить и ряд ярких российских исследователей ${ }^{1}$. Хорошо известна связь этой традиции

1 Одна из первых отечественных работ на эту тему - Руткевич А.М. От Фрейда к Хайдеггеру: Критический очерк экзистенциального психоанализа. М., 1985. Также см.: Попова Н.Г. Французский постфрейдизм: критический анализ. М., 1986; Власова А.О. Антипсихиатрия: становление и развитие. М., 2006; Дьяков А.В. Феликс Гваттари, философ трансверсальности. СПб., 2012; традицию психофилософии продолжает Вадим Руднев. См. его: «Словарь безумия» с лингвистикой и антропологией благодаря разработке и привлечению во все эти сферы структуралистского метода. Но если поставить вопрос шире и выявить общие методологические основания теоретизации психопатологии, то мы обнаружим в основе знания о психическом инвариант, организующий западное знание в целом: механицизм в широком смысле. Позитивное знание в западной культуре сводится к приведению определенной области реальности в соответствие с

(Руднев В.П. Словарь безумия. М., 2005). В разработку этой традиции внесла свой вклад и Н.С. Автономова, выступившая переводчиком словаря по психоанализу Лапланша и Понталиса (Лапланш Ж., Понталис Ж.-Б. Словарь по психоанализу (PUF, 1967). 2-е перераб. изд. М., СПб.-М., Центр гуманитарных инициатив, 2010 (1-е изд. М., Высшая школа, 1996)), а также уделившая внимание психоанализу Лакана (Автономова Н.С. Познание и перевод. М., 2008. С. 211-352). Психофилософской является и работа Ф.И. Гиренка «Аутография языка и сознания» (Гиренок Ф.И. Аутография языка и сознания. М., 2010). В междисциплинарном поле философии, психологии, психиатрии и психоанализа давно и плодотворно работает П.С. Гуревич.

Статья подготовлена при финансовой поддержке РФФИ, грант № 13-06-00813a «Эволюционное мыцление как основа междисииплнарного синтеза знания» 


\section{Психология и психотехника 5(56) • 2013}

представлениями о механизме или системе как о сложной целостности, совокупности гомо- или гетерогенных элементов, объединенных отношениями определенного типа. Далее, эволюция представлений о механизме (механизм - организм - структура - система) $)^{2}$ достаточно быстро приводит исследователей к выводу об эволюции механизма. Другими словами, создавая все более сложные механизмы и наблюдая этот процесс усложнения рукотворных механизмов, западный человек быстро приходит к идее развития естественных живых «механизмов», таких как организм, общество, а позже и сознание. Создание сложного механизма парового двигателя и разработка понятия «движущей силы» (Карно, Клаузиус, Джоуль), которое позже будет заменено понятием «энергия» (Томсон) ${ }^{3}$, завершают эту модель развивающегося (в смысле «повышающего свою сложность, уровень дифференциации») механизма (позднее «системы»), представляющего из себя совокупность элементов с циркулирующей по ним энергией, обеспечивающей взаимодействие этих элементов и заставляющей данный механизм выполнять некоторую работу. Важно подчеркнуть, что все элементы системы механицистских представлений были осмыслены практически одновременно - в середине девятнадцатого столетия: «Принципы психологии» Спенсера - 1855 г., «Происхождение видов» Дарвина - 1859 г., Томсон ввел в научный обиход термин «энергия» в 1848 г. К концу девятнадцатого столетия эта модель эволюционирующей системы с циркулирующей по ней энергией уже активно использовалась психиатрами и неврологами. Посмотрим, какие результаты она принесла в области изучения психического.

\section{Зарождение эволюционной теории психического}

Проблематизация психического началась благодаря безумию: безумие с его пугающими и опасными жестами заставило человека очертить область психического и разрабатывать ее до тех пор, пока все его возможные проявления не будут вписаны в нее и усмирены сред-

\footnotetext{
2 Оговоримся сразу, что сами исследователи - например, Эй или Берталанфи - часто определяли свои взгляды как противоположные механицизму, естественно предлагая вместо понятия «механизм» понятие «система», «структура» или же «организм». У них, разумеется, были серьезные основания утверждать подобное, поскольку предлагаемые ими новации в масштабе сделанного ими шага и впрямь были достаточно серьезны. Однако при взгляде под более широким углом все они предстают как разработчики последовательных этапов развития представлений о механизме.

3 Об этом см.: Кудрявцев П.С. Курс истории физики. М., 1982. C. 209, 225.
}

ствами, добытыми в процессе этой разработки. (Как известно, процесс этот все еще далек от завершения). Уже в древнем мире поведение безумца воспринималось как знак, указывающий на некое событие, лежащие в области, отличной от области поведения: жесты безумия довольно быстро были осмыслены как симптом. Симптом указывал на два типа событий: либо событие из области взаимодействия с потусторонними силами (богами, бесами и т.п.), либо событие из области телесных недугов ${ }^{4}$. Позитивное знание на протяжении всей своей истории стремилось вывести все большую часть симптомов изпод юрисдикции потустороннего и привязать к телу. В последние двести лет, когда наука наложила табу на любую апелляцию к темным и светлым силам, место потустороннего заняло психическое, и причины болезни стали делиться на психологические и органические. Разумеется, не замедлили явиться две партии психиатров: те, что считали, что причины психопатологии имеют прежде всего психологический характер (сторонники психогенеза), и те, что искали истоки главным образом в повреждении тела (сторонники органогенеза). Однако изучение тела шло стремительно (его просто вскрывали и рассматривали, ставили опыты над животными и т.д.), а как подобраться к душе, «психэ», отличными от религиозных путями было совершенно неясно. Прорыв произошел в тот момент, когда изучение тела достигло того уровня, на котором стали возможны философские обобщения и работа с абстрактными понятиями: тело было уподоблено автомату (Борелли, Декарт). Вслед за телом механические принципы организации были приписаны и душе (Декарт, Гоббс, Локк). Но поначалу большого эффекта эта аналогия не имела: вплоть до середины XIX в. прогрессивно мыслящие психиатры предпочитали усматривать причины психических расстройств в болезнях тела.

В этом отношении важнейшим событием в истории психиатрии стало описание прогрессивного паралича, представленное научному миру А.Л. Бейлем в 1822 г. И дело было не только в том, что впервые была строго зафиксирована и описана болезнь, сопровождавшаяся психической симптоматикой, которой соответствовали органические повреждения, легко выявлявшиеся при вскрытии (воспаление паутинной оболочки головного мозга). Психическое заболевание окончательно перестало восприниматься как случайное единичное событие, превратившись в длительный и закономерный процесс. Кроме того, психические болезни были однозначно связаны с повреждением мозга, исследование которого положило начало неврологии и дальнейшей разработке

4 См. подробную и ставшую уже классической работу Каннабиха: Каннабих Ю. История психиатрии. М., 2002. 


\section{Открытий чудных...}

понятия «нервной системы». Фактически был открыт еще один вид механизмов: механизм нервных клеток и волокон, служащих проводниками нервных импульсов.

Динамическое видение психопатологического процесса способствовало пониманию психической болезни как вырождения, то есть процесса, обратного развитию, эволюции (Б.О. Морель, Ч. Ломброзо).

Но подлинным основателем эволюционной психологии (и, как следствие, психиатрии) по праву считается Герберт Спенсер (1820-103). В своих «Принципах психологии» (1855) он представил ментальное развитие, эволюцию, как постепенный переход к все более сложным и дифференцированным состояниям. Обратный эволюции процесс он назвал диссолюцией. Считая психику механизмом адаптации человека к окружающей среде, Спенсер выводил ее из восприятия, показывая, что у дикаря в сознании доминирует восприятие, а у более развитого эволюционно западного человека рациональное мышление. Тем самым Спенсер укрепил европоцентризм и представления об эволюционной неполноценности «примитивных» народов по сравнению с европейцами. Важно, однако, подчеркнуть, что Спенсер не считал себя материалистом, и не постулировал зависимости сознания от тела. Скорее он рассматривал их соотношение как параллелизм.

\section{Дж.Х. Джексон: психическая болезнь как диссолюиия}

Высказывание Спенсера о том, что «доктрина эволюции в ее чисто научной форме не включает материализма, хотя ее оппоненты настойчиво представляют ее таковой», цитирует в своих Крунианских лекциях ${ }^{5}$ один из главных героев нашего исследования - невролог Джон Хьюлингз Джексон (1835-1911), специализировавшийся на исследовании эпилепсии, одна из форм которой названа его именем. Джексон - казалось бы классический позитивистски настроенный исследователь психического, образцовый врач своей эпохи. Разрабатывая на тот момент совершенно новую, но такую многообещающую область, как неврология, он успешно связывает повреждения определенных центров мозга с симптомами, наблюдаемыми у эпилептиков. Признавая очевидную связь между нарушениями церебральной деятельности и неврологическими патологиями: эпилепсия и вызванный ею временный паралич, гемиплегия, хорея (пляска святого Витта), прогрессирующая мускульная атрофия и афазия, - он, тем не менее,

5 Hughlings Jackson J. Evolution and dissolution of the nervous system. Croonian Lectures delivered at the Royal College of Physicians, March 1884. Lancet 1884. осознает, что далеко не все психические болезни столь же легко и однозначно увязываются с поражениями нервной системы.

Джексон выстраивает собственную эволюционную теорию иерархической организации нервной системы, представляя мозг как слоистое образование, каждый последующий слой которого отвечает за все более произвольные, менее автоматичные действия. Эта мысль весьма важна для нас, поскольку она отражает общую тенденцию развития механицистского мировоззрения через органицизм (к которому относят и Джексона), структурализм и теорию систем к синергетике. Джексон заявляет, что хотя человек с физической точки зрения есть автомат, сенсорно-моторный механизм, по которому - это для нас важно! — циркулирует нервная энергия, высшая часть его нервной системь наименее автоматична. То есть, человек эволюционирует от автоматических, обусловленных действий к свободе, которая необходима ему для адаптации к новым условиям окружающей среды. Этот этический вектор - от обусловленности к свободе - важнейший подарок эволюционизма механицизму в результате прививки последнего на антропологическую почву. Можно сказать, что, примененный к живому, механицизм обрел горизонт самопреодоления: постепенное усложнение био-автомата до сложной живой системы обеспечило переход от детерминизма к спонтанности, причем точкой такого перехода стали высшие центры нервной системы.

Психическое заболевание Джексон рассматривает как процесс, обратный эволюции, заимствуя у Спенсера термин «диссолюция». Диссолюция психического представляет собой полное или частичное разрушение высших центров, ответственных за наиболее произвольное поведение, и, как следствие, передачу управления нижележащим центрам, ответственным за поведение более автоматичное. Отсюда - многочисленные автоматизмы у психических больных. Однако же, частичная диссолюция не означает полной отмены эволюционных тенденций. Даже с частично разрушенными высшими центрами человек продолжает поддерживать достижения эволюции на тех уровнях, которые пока не затронуты болезнью. Поскольку более поздние и более высшие центры тормозят функции нижележащих, то при их разрушении эти нижележащие получают свободу. Отсюда - разделение на позитивные и негативные симптомы: негативные возникают по причине разрушения высших, а позитивные - высвобождения нижележащих функций. Поэтому такие симптомы, как иллюзии, бред, галлюцинации, следует считать не негативными проявлениями болезни, а позитивными результатами усилий поврежденной, но все еще упорствующей, борющейся личности, реконструирующей собственную реальность 


\section{Психология и психотехника 5(56) • 2013}

имеющимися у нее силами. Иллюзии безумца - это его перцепции. Этот удивительно гуманный и свежий для современной ему психиатрии вывод является одной из первых попыток построения психологии больного не из перспективы нормы и исключительно в терминах патологии, но как «другой» психологии, альтернативного способа собирания реальности, о котором будет сказано столь много во второй половине XX в.

Анри Эй, последователь Джексона, на которого его учение о позитивных и негативных симптомах произвело сильное впечатление, первую свою работу посвятил галлюцинациям. Но прежде чем перейти к его теории органодинамизма и психического тела, необходимо упомянуть еще одно имя - самое известное в области исследования психического в современной западной культуре. Когда мы сказали, что Джексон, отдавая дань поражениям нервной системы как причинам определенного типа патологий, оставлял в науке о психическом место для совершенно иных болезней, не сводимых с той же легкостью к неврологическим причинам, мы имели в виду, в том числе, различные проявления истерии, исследование которых привело Зигмунда Фрейда к разработке его психоаналитического метода и положило начало психоанализу как психо-философской антропологической концепции.

\section{Фрейд: психический аппарат, энергия либидо и эволюционизм}

В случае с концепцией Фрейда мы, как и в случае с Джексоном, имеем весь интересующий нас набор: механицизм (структурализм), эволюционизм и энергетическую теорию либидо. Немаловажно, что, начиная как невролог, Фрейд ознакомился и с работами Джексона, воздав ему должное в своем раннем тексте 1891 г. «Вклад в концепцию афазии». Впрочем, Джексон был далеко не единственным источником влияния на молодого Фрейда. В тот период энерго-механицистские модели принципов работы мозга и нервной системы уже становились весьма популярны ${ }^{6}$. У самого Фрейда уже в студенческие годы возник проект, который в переработанном виде ляжет в основу его метапсихологии: мозг - специфическая структура, по которой циркулирует нервная энергия, количество которой управляется принципами инерции (тенденцией к полному разряду) и устойчивости (тенденцией сохранять постоянной сумму возбуждений). С точки зрения зрелого Фрейда психика индивида раз-

6 Упомянем из старших современников психофизика Г.Т. Фехнера и Г. Сакса с его принципом сохранения психической энергии, а из ровесников - автора концепции психологической эволюции личности Пьера Жане и его психическую энергию, характеризующуюся силой и напряжением. вивается в направлении, аналогичном направлению развития культуры: в направлении подавления и усмирения первичных позывов (импульсов), сублимации либидо. По сути, индивидуальный психический аппарат, также как и система культуры, есть повышающий степень своей сложности механизм распределения потоков либидо, специфической взгонки либидозной энергии. Психическая болезнь трактуется как срыв, неизбежная жертва эволюции либидо; больной - досадный побочный эффект эволюции, неудачная особь, не способная адаптироваться к возросшим требованиям культуры в отношении контроля своих первичных импульсов ${ }^{7}$. Психические расстройства есть следствие частичного регресса, отката на предыдущие фазы психического развития ${ }^{8}$.

То, что Фрейд отталкивается от конкретной личности с уникальной (хоть и характеризующейся некими универсальными фазами) психической историей в отличие от Джексона, исходящего из единой для всех людей органицистской неврологической теории, свидетельствует о том, что мы от соматического или органического объяснения психопатологии перешли к объяснению психологическому: если самым удобным для иллюстрации собственных взглядов заболеванием для Джексона является эпилепсия, то Фрейд строит свою теорию, изучая истерию. В этот период в психиатрии сторонники психогенеза берут реванш над поборниками органогенеза. В психиатрическую практику проникают психоаналитические методы, а в теорию - концептуальные наработки психоанализа. Это приводит к очередному пересмотру классификации психических болезней, в результате которого возникает термин «шизофрения», открывающий новый этап в развитии знания о психическом ${ }^{9}$.

\footnotetext{
7 Эта мысль проводится им в том числе в статье «Неудовлетворенность культурой».

8 О влиянии идей Дарвина на Фрейда см.: Sulloway F. Freud, biologist of the mind. Beyond psychoanalytic legend. London, 1979.

9 Термин «шизофрения» впервые вводит О. Блейлер, используя фрейдовский термин «spaltung» — «расщепление» в его переводе на греческий. До Блейлера почти повсеместно была принята классификация Крепелина, в которой место шизофрении занимала "ранняя деменция», dementia praecox, которая, однако, сильно отличалась от шизофрении тем, что начиналась исключительно в молодом возрасте и заканчивалась собственно деменцией, то есть более- менее полным распадом личности. Именно благодаря психоанализу Фрейда и Юнга удалось «увидеть» вместо ранней деменции гораздо более обширную группу патологий с интереснейшим продромальным периодом, когда больной как раз и обнаруживает в своем бреде символы, которыми занимается психоанализ.
} 


\section{Открытий чудных...}

\section{От эволюиионной психиатрии к «Психиатрической эволюции»}

В 1925 г. ученик Ойгена Блейлера Эжен Минковски создает в Париже группу «Психиатрическая эволюция», а позже вместе с Анри Кодэ начинает выпускать журнал с тем же названием. Название «Психиатрическая эволюция» отнюдь не случайно. Во-первых, Эжен Минковски пришел в психиатрию через философию, и не в последнюю очередь - через философию Анри Бергсона. Его диссертация по психиатрии называлась «La notion de perte de contact vital avec la réalité et ses applications en psychopathologie» («Понятие утраты контакта с реальностью и его применение в психопатологии»), где он рассуждает об основном (по Блейлеру ${ }^{10}$ ) симптоме шизофрении - утрате контакта с реальностью или аутизме - в терминах жизненного порыва Бергсона. В дальнейшем он разовьет идеи Бергсона в самом знаменитом своем труде «Temps vécu» («Прожитое время»). Таким образом, в проекте «Психиатрическая эволюция», как и в трудах его основателя, на основе эволюционной идеи осуществляется синтез психиатрии, психоанализа и философии. Конечно, это не значит, что до этого проекта эти три области были разделены: напротив, Минковски продвигает во французской психиатрической среде, имевшей к тому моменту свои богатейшие традиции и блестящую плеяду психиатров (Эскироль, Пинель, Морель, Моро де Тур, Байарже, Шаслен, Клерамбо, Шарко, Жане и другие) и постоянно соперничавшей с немецкой психиатрией, идеи представителя немецкой психиатрической традиции Ойгена Блейлера, который уже осуществил в своих работах синтез органицистской психиатрии (в которой главным авторитетом на тот момент был Крепелин) и психоанализа Фрейда. Усилиями Минковски психоанализ укореняется во Франции (чтобы в лице Жака Лакана и его школы пустить новый оригинальный побег уже в рамках структурализма). Одновременно закладываются основы того, что в XX в. будет пониматься под французской психиатрической традицией, для которой характерен взгляд на патологию как на «другую» норму (в отличие от установки немецкой психиатрии на жесткое противопоставление нормального и патологического), тенденция к размыванию границ между нозологическими единицами, восприятие конкретных типов психопатологии как в большой степени условных (в отличие от приверженности немецкой психиатрии к установлению жестких границ между видами болезней

10 Используя понятие «аутизм», считающееся сокращением фрейдовского «аутоэротизм», О. Блейлер делает его главным симптомом, по которому ставится диагноз «шизофрения». и стремления дать каждой из них четкое описание со своей характерной симптоматикой), философская нагруженность психиатрической теории и, как следствие, большая готовность применять психоанализ к психозам, не ограничиваясь малой психиатрией (неврозами и пограничными состояниями). Все эти характерные черты французской психиатрической теории поспособствуют быстрой ассимиляции во второй половине ХХ в. антипсихиатрических идей и так называемого фрейдомарксизма, трактующего психопатологию как следствие конфликтов в буржуазном капиталистическом обществе, дальнейшей либерализации и гуманизации обращения с психическими больными во Франции, а также окончательного размывания главного психического диагноза ХХ в. - шизофрении - не в последнюю очередь благодаря постмодернистской психофилософии (М. Фуко, Ж. Делёз, Ф. Гваттари).

Кроме того, понятие «Психиатрическая эволюция» отсылает к еще одной эволюционной идее, работающей на этот раз на мета-уровне: эволюционирует не только мозг и психика биологического вида «человек», и не только психиатрическое знание, эволюционируют также и формы психопатологии. Еще Карл Ясперс заметил, что до XVIII в. главным психическим расстройством была истерия, а с XIX таковым стала шизофрения, делая вывод, что в психической болезни словно бы отражается некий «дух эпохи». Положим, сама периодизация вызывает вопросы. Мы-то уже знаем, что в позитивистски ориентированном XIX в. с его ориентацией на органогенез в противовес психогенезу типичным расстройством признавали сначала общий паралич (с его очевидными органическими поражениями) и дававшую быструю картину деменции «деменцию прекокс». Затем у общего паралича была выявлена сифилитическая этиология, а успехи психоанализа подняли на щит истерию, которая недолгое время считалась эталонным психическим заболеванием, пока на сцену не вышла шизофрения. Разумеется, подобные перемены в истории собственной науки были замечены психиатрами. Возникли теории социальной этиологии психической болезни. В частности, основатель этнопсихиатрии Жорж Деверё (George Deveruex) писал, что шизофрения - участь умирающих культур, поскольку ее случаи учащались в Риме и Спарте периода упадка, но были почти неизвестны в Классической Греции V-IV вв. до н.э., страдавшей главным образом более благоприятной в отношении течения и прогноза истерией. Новая вспышка шизофренических расстройств на Западе свидетельствует о терминальной стадии этой культурной формации.

Коль скоро озадачились влиянием общества на генезис психопатологии, не могли обойти вниманием главную ячейку общества - семью. Появляются по- 


\section{Психология и психотехника 5(56) • 2013}

нятия шизофреногенной матери и шизофреногенной семьи. В пятидесятые годы набирает влияние так называемая группа Пало-Альто в Калифорнии (Г. Бейтсон, Д. Хейли, Д. Уикленд, Д. Джексон), развивающая семейную этиологию шизофрении, в язык психиатров входит знаменитое двойное принуждение или двойная связь (double bind). Бейтсон и его группа, отталкиваясь от теории систем и кибернетики, используют понятие семейной системь, которая стремится к гомеостазу. Тогда странное поведение психических больных может быть объяснено как гомеостатический механизм, вырабатывающийся в семье с особыми патологическими способами коммуникации. Как мы видим, семья постепенно осмысливается как саморегулирующяаяся система, а психический больной - как элемент этой системь, чья патология - результат адаптации к патологическим отношениям в этой системе. Роль же энергии выполняет информация, которой элементы системы обмениваются в процессе коммуникации. Конечно, создатели системной семейной терапии вдохновлялись не паровым двигателем и термодинамикой Карно-Клаузиуса, а кибернетикой Винера, но, как мы видим, их энегро-механицистская модель не сильно изменилась со времен Фрейда и Юнга ${ }^{11}$.

Все эти теории социогенеза шизофрении вкупе с шокирующим опытом Второй мировой войны, когда нацисты уничтожали, морили голодом и стерилизовали оказавшихся в их власти умалишенных, к которому добавилась постепенно просачивающаяся информация о политических заказах на диагноз «вялотекущая шизофрения» в хрущевском Советском Союзе в связи с борьбой с инакомыслием, окончательно закрепили за психическими больными статус несчастных жертв социальной несправедливости, дисгармонии и политического произвола: созрели все условия для выхода на сцену антипсихиатрии. Но прежде чем мы перейдем к философу, наиболее ярко представляющему это течение во Франции, Мишелю Фуко, необходимо подробнее остановиться на одном из его учителей, ознаменовавшем целую эпоху во французской психиатрии.

\section{Анри Эй: органо-динамизм, психическое тело}

Влиятельнейший французский психиатр Анри Эй, последователь Джексона и Блейлера, возглавивший после Минковски журнал «Психиатрическая эволюция», а в 1946 г. организовавший в больнице Бонневиля (в последствии получившей к своему названию добавление «имени Анри Эя») коллоквиум по проблеме психогенеза неврозов и психозов, в дальнейшем стал председателем

11 Юнг К. Об энергетике души. М., 2010.
Первого Конгресса психиатров (1950 г.), а затем и генеральным секретарем основанной по результатам этого конгресса Всемирной Психиатрической Ассоциации. Занимаясь, как нетрудно догадаться, в первую очередь проблемами шизофрении, Эй пытался применить к описанию этого сложного, многоликого и трудноуловимого заболевания концепцию иерархической организации психической структуры Джексона и его идею позитивных и негативных симптомов.

В мысли Эя и его теории шизофрении мы в очередной раз встречаем те составляющие, исследованию взаимосвязи которых и посвящена данная статья: органицизм, структурализм и иерархию уровней (являющиеся неизменными составляющими развитого механицизма), эволюционизм и связанный с ним динамизм. Изначально Эй вместе с Минковски развивал концепцию шизофрении Блейлера. Позже его внимание привлекла иерархическая теория психических функций Джексона, и в 1938 г. выходит монография А. Эя в соавторстве с Жульеном Руаром (Gulien Rouart) «Попытка применения принципов Джексона к динамической концепции нейро-психиатрии». Эй, как и многие до и после него, по собственному признанию стремится преодолеть альтернативу органицизм - психизм, или, в его собственной формулировке, «вырвать психиатрию из механицизма, который ее парализовал, и психодинамизма, который ее выпарил» ${ }^{12}$. Учитывая влияние Гегеля на интеллектуальный климат той эпохи, не удивительно желание Эя создать теоретическую модель, которая бы их «объединила и превзошла». В результате, по собственному признанию автора, дуализм физического и морального был заменен параллелизмом, которого придерживались и Спенсер, и Джексон. Но был и синтез - «психическое тело», с распадом которого с точки зрения Эя связана психическая патология. Однако, если вчитаться в те понятия, которые Эй привлекает для его описания, то мы увидим старый добрый механицизм, поскольку распад психического тела есть дезинтеграция «интеграла психизма», переход «онтологической структуры бытия от негэнтропии к энтропии» ${ }^{13}$. Для нас важно также, что Эй сохраняет понятие диссолюции Джексона в отношении психической патологии, поскольку полагает, что в ее результате не происходит психической смерти: человек в результате такого регресса не становится трупом, скорее он возвращается к эмбриональным формам психического существования (обращение вспять индивидуальной психической эволюции). Это сопоставление безумца с ребенком Мишель

12 Ey H. Des Idees de Jackson a un model organo-dynamique en psychiatrie. Paris: Monterrey, 1997. P. 10-11.

13 Ibid, p. 11. 


\section{Открытий чудных...}

Фуко позже классифицирует как миф, который весьма живуч, поскольку действует успокаивающе на сознание наблюдающего психическое заболевание.

\section{М. Фуко: от микрофизики власти к техникам себя}

Первая книга Фуко - «Психическая болезнь и личность» - в которой высказан этот упрек, дает синхронный срез современного знания о безумии. Эволюционная перспектива объяснения генезиса психопатологии превращается здесь в одно из трех фундаментальных «измерений» болезни наравне с историческим (позднее он явным образом противопоставит термины «история» и «генеалогия», здесь же он использует их параллельно) и экзистенциальным. Таким образом, Фуко отдает дань наиболее влиятельным с его точки зрения концепциям психической болезни современности: эволюционной психиатрии (Джексон, Эй, Монаков, Мург), психоанализу (Зигмунд и Анна Фрейд, Блейлер) и экзистенциальному анализу и экзистенциальной психиатрии (Ясперс, Кун, Бинсвангер, Сешехэ (M. Sechehaye)). Но сам он предлагает, разумеется, другое понимание генезиса и природы психической болезни, и чтобы его выделить, определяет его как «условие болезни».

Это разделение на измерения болезни и ее условие является, как мы понимаем, методологическим, и в нем самом по себе отражается и анонсируется эпистемологическая перспектива, в которой Фуко будет работать всю жизнь. В той мере, в какой его интересует знание, дискурс, Фуко выделяет социальную перспективу как привилегированную, показывая, что именно общество, в конечном итоге, дает санкции на те или иные формы знания о болезни, то есть уже в «Психической болезни и личности» намечается концепция власти-знания, которую он разовьет позже. Далее, определение эволюционной, исторической (генеалогической) и экзистенциальных перспектив как «измерений» психической болезни свидетельствует, что мы уже в пределах пространственной философии - прямого следствия преломления структурализма в философском контексте.

Но для нас прежде всего важно то замечание, которое Фуко выносит во введение: «Если так сложно определить психологические болезнь и здоровье, то не потому ли, что мы вновь и вновь тщетно стараемся использовать по отношению к ним понятия соматической медицины? Не появляются ли сложности в установлении единства органических нарушений и изменений личности постольку, поскольку мы признаем для них одну и ту же причинность? По ту сторону психической и органической патологии располагается общая и абстрактная патология, которая господствует над ними, навязывая им предрассудки, дефиниции и диктуя как сходные методы, так и сходные постулаты» ${ }^{14}$.

Теперь зададимся вопросом: что это за абстракция, объединяющая психическое и соматическое, задающая для них общую систему причин и навязывающая им дефиниции и методы одного порядка? Мы уже упоминали ее, и имя ей - «механицизм». Именно механицистская парадигма является основой всего западного знания, предлагая свой шаблон - механизм, автомат, структуру, систему и даже организм ${ }^{15}$ - для каждой области, в которую это знание вторгается, или, правильнее сказать, которую оно учреждает по одному и тому же лекалу. Верно и то, что соматическая медицина стоит к этому шаблону ближе, чем психическая, на которую он пока - ложится с серьезными натяжками. Но выбора у нас нет. Все, что нам остается - это развивать свои представления о механизме.

К счастью развитие, эволюция - это то, что внутренне присуще идее механизма: увеличение элементов, частей, усложнение системы связей между ними, все большее разнообразие маршрутов циркуляции энергии по системе, умножение ее уровней и диверсификация связей между уровнями, группировка и перегруппировка в блоки внутри системы и возникновение новых отношений уже между блоками, подсоединение новых элементов извне, подключение дополнительных энергетических потоков, - вот те экстенсивные пути развития, которые для нас открыты. Бесконечное количественное наращивание системного ресурса. Больше элементов, больше скорости, больше энергии. До какого-то момента казалось, что, как бы далеко мы не заходили по этому пути, во всем этом - еще «слишком много аграрного», слишком много архитектурного, то есть, слишком много пространства, как сказал бы Делёз, а также времени, понятого как пространство, как сказал бы Бергсон. И были бы, безусловно, правы, если бы пространство не начало искривляться, а время не обнаружило обратимость. Но этими проблемами занялся уже Жиль Делёз.

Что же касается самого Фуко, то и ему, разумеется, не удалось уйти от этой безальтернативной абстракции механизма, причем, как и положено, вкупе с идеей его (механизма) развития. В дальнейшем Фуко разработает концепцию дискурсивной реальности, сотканной из отношений власти-знания; реальности, которая постоянно усложняясь, повышает степень своей дифференциации

14 Фуко М. Психическая болезнь и личность / Пер. О.А. Власовой. СПб., 2010. С. 66.

15 Понятие «организм» можно генетически вывести из применения к живому телу концепции механизма, что косвенно покажет Ж. Делёз в своем концепте тела без органов. 


\section{Психология и психотехника 5(56) • 2013}

(микрофицируется), опутывая все более тонкой и частой сетью отношений все свои явления и, тем самым, делая их более сложными и детализированными. Дискурс, который является специфической матрицей, носителем и вместилищем отношений власти-знания, есть по сути сверхсложная эволюционирующая (повышающая свою сложность, микрофицирующаяся) структура, состоящая из под-структур, которые Фуко именует диспозитивами. Благодаря все более изощренному процессу проработки и повышения сложности дискурсивных отношений, посредством специфического вгибания, инфлексии дискурса о самом себе («техники себя») человек прорабатывает постепенно свое «внутреннее пространство», бесконечно усложняя его до тех пор, пока оно не станет настолько богатым и разнообразным, что сможет конкурировать по степени реальности с реальностью «внешней». И тогда перспектива переворачивается: внутреннее, субъективное, «Я» становится исходным (онтологически и психологически), а внешнее, объективное - производным. Материализм как мировоззрение сменяется идеализмом, на смену необходимости приходит свобода. Впрочем, эта последняя планка будет взята Фуко уже перед самой смертью, когда произойдет его знаменитый поворот к субъекту, то есть его собственная философия будет развиваться и эволюционировать точно в соответствии с логикой всякой эволюционной идеи: от необходимости к свободе.

Но вернемся к молодому Фуко, продвигающему во французской философии идеи феноменологической психиатрии Бинсвангера, к работе «Сон и существование» которого он написал предисловие (по объему в два раза превышающее текст собственно Бинсвангера), но уже отчетливо отдающему предпочтение фрейдомарксизму с его пониманием психической болезни как реакции на социальный конфликт.

Заявленная в «Психической болезни и личности», тема психического расстройства как социально-культурного (в дальнейшем - дискурсивного) феномена становится основной в «Истории безумия в классическую эпоху» ${ }^{16}$. Подхватив незаконченный проект естественной истории безумия Анри Эя, эта книга представляет из себя генеалогию безумия в ницшеанском смысле, но также и его археологию в смысле фрейдовском, причем Фуко здесь впервые в явном виде покажет, что одно и есть другое, что "раскопки» прошлого всегда предполагают «реконструкцию» этого прошлого из текущих условий настоящего с привлечением тех актуальных познавательных схем, которыми располагает исследователь, приступающий к подобным изысканиям. Подобное превращение истории в генеало-

16 Фуко М. История безумия в классическую эпоху. СПб., 1997. гию (о котором Фуко уже в явном виде напишет в статье 1971 г. «Ницше, генеалогия, история» ${ }^{17}$ ), то есть подобная трактовка знаменитой археологической метафоры Фрейда будет иметь далеко идущие последствия прежде всего для самого психоанализа, поскольку не позволит более ни психоаналитику, ни его пациенту пребывать в уверенности, будто в процессе психоанализа действительно «вскрываются» некие древние пласты личности анализанда, сформировавшиеся в его раннем детстве: скорее психоаналитик осуществляет подмену текущих реальных конфликтов своего пациента мифическими и искусственными «эдиповыми» конфликтами, которых у того может не быть вовсе. Все дело во внушении. И как мы понимаем, идея этого внушения может быть мощно заряжена политически, ибо (как мы помним еще со времени «Психической болезни и личности») реальные проблемы пациента имеют социальное происхождение, a аналитик подменяет их семейной мифологией. Другими словами, от политического и общественного, то есть от общечеловеческого, психоанализ опять уводит человека к внутрисемейному, стараясь хитростью удержать его в состоянии искусственно сфабрикованного психического детства. Эту тему заострят и разовьют в работе «Капитализм и шизофрения 1. Анти-Эдип» ${ }^{18}$ Ж. Делёз и Ф. Гваттари. В данной работе, возможно, в последний раз, и оттого особенно ярко в междисциплинарном поле философии, психоанализа и психиатрии сработали исследуемые нами здесь темы эволюционизма, механицизма и либидинальной энергетики.

\section{«Капитализм и иизофрения»}

Прежде всего, книгу «Капитализм и шизофрения 1. Анти-Эдип» Ж. Делёза и Ф. Гваттари не стоит рассматривать как серьезную попытку дать определение и описать «сущность» болезни шизофрении. Строго говоря, отношение этого текста к шизофрении как минимум проблематично, и чтобы понять его ироничный подтекст, желательно иметь представления о перипетиях термина «шизофрения» в этот период ${ }^{19}$. Первая часть «Капитализма и шизофрении» ${ }^{20}$ иллюстрирует на практике фукианскую идею о диспозитиве «психическая болезнь»: это понятие появляется в дискурсе не столько благодаря «изучению»

\footnotetext{
17 Ницше и современная западная мысль. Сборник статей / под ред. В. Каплуна. СПб.; М., 2003. С. 532-559.

18 Deleuze G. Guttari F. Capitalisme et schizophrénie 1. L'AntiOedipe. Paris, 1972.

19 См. работу Гаррабе Ж. История шизофрении. М.; СПб, 2000 .

20 Существует также «Капитализм и шизофрения 2. Тысяча плато».
} 


\section{Открытий чудных...}

некоей «сущности» той или иной болезни, сколько для решения политических, идеологических, экономических, философских и прочих задач. Эта работа - своего рода пародия на современную ей психофилософию, в полном соответствии с постмодернистской самоиронией ставшая одновременно ее «хауптверком». И действительно, главная проблема безумия в том, что тот, кто о нем пытается рассказать, ничего о нем не знает, а тот, кто знает, ничего не может рассказать. (В случаях, когда безумец выздоравливал и связно излагал пережитый опыт, его диагноз сразу задним числом облегчали, определяя не как психоз, но как истерию или псевдоневроз. Так что невыход из психоза стал специфическим знаком его качества, основанием для постановки диагноза, правда, всегда задним числом.) Поэтому психическая болезнь превратилась в пустой термин, в который при желании и сноровке оказалось возможным загружать почти любые содержания. Возможно, именно такого рода понятия стали моделью, эталоном постмодернистской дискурсивной реальности, в которой нет ничего подлинного, и где слова «изображающие» вещи - есть лишь узлы в сети сложных соотношений подвижных потоков смысла, частично канализируемого и структурируемого текущей культурной матрицей. Делёз и Гваттари словно говорят нам: ну, коль скоро все кому не лень подлаживали понятие шизофрении под собственные исследовательские, политические, идеологические, личностные интересы, то и мы сделаем то же самое. В результате возник философско-политический концепт, в лучших традициях модной на тот момент антипсихиатрии, отражающий не столько страдания, сколько мировоззренческую позицию шизо-субъекта.

Нам эта работа интересна прежде всего потому, что в ней иронично и блестяще подаются все основные понятия, которым посвящена данная статья.

Bo-nервых, «Анти-Эдип» предлагает нам свою реконструкцию шизо-реальности как реальности, состоящей из бесчисленных и бесконечных цепочек последовательно подсоединенных друг к другу «желающих машин». В этой последовательности размываются, стираются все фундаментальные дихотомии обыденного мира: человек-природа, производство-потребление, объект-субъект, папа-мама и т.д. Есть только машины, машины машин. Конечно, это - пародия на панмеханицизм западной культурь. (Следует учитывать, что Феликс Гваттари интересуется теорией систем ${ }^{21}$

21 Применение теории систем в психиатрии - отдельная большая тема. У нас нет возможности рассматривать ее в рамках данной статьи. Стоит лишь указать, что в советской психиатрии возникла и существует до сих пор школа системно-эволюционного подхода П.К. Анохина - В.Б. Швыркова, применяющая теорию функциональных систем к области нейрофизиологии. и кибернетикой.) В конечном итоге оптика западного знания способна везде увидеть только механизмы, и шизофрения как истинная болезнь эпохи доводит эту тенденцию до абсурда. Делёз и Гваттари ставят диагноз: мы все больны механицизмом!

Во-вторых, эти цепочки желающих машин подсоединены друг другу не просто так: таким образом они проводят потоки либидо. То есть, шизо-реальность энергетична.

В-третьих, существует эволюиия от невроза к nсихозу, от эдипова треугольника «мама-папа-сын» к бинарно-линеарным отношениям желающих машин. Эта эволюция (в лучших традициях фрейдизма) работает как на уровне онто- так и филогенеза. Индивид, вырастая из семейных отношений с их невротической основой, дорастает до восприятия себя как элемента социума, для которого характерна параноидная установка (вокруг - одни конкуренты; параноидный мир наполнен опасными и агрессивными частичными объектами: съешь, или будешь съеденным ${ }^{22}$ ), и далее как части универсума, что требует шизо-установки: всеобщей одухотворенности природы и связи всего со всем, которую символизирует Тело Без Органов. С точки зрения развития интеллектуального схватывания реальности происходит развитие от эмпирического экспериментального знания (невроза) к откровению (психоза) ${ }^{23}$. Но то же самое происходит и на общекультурном уровне. Эдипальная фаза человечества - это древнее состояние, когда человек усваивает запрет на инцест и овладевает символом. Варварство и деспотические империи соответствуют параноидной стадии, а капитализм - естественно, шизофренической. Но на самом деле все еще сложнее, поскольку желающие машины всегда составляли основу психической жизни, а Эдип лишь выкраивал, вырезал из их цепочек нужные ему фигуры, в соответствии с собственными целями купируя или усиливая потоки либидозной энергии. В каком-то смысле созревающий психически индивид переживает по Делёзу и Гваттари в обратном порядке свой собственный психогенезис, поскольку в соответствии с кляйнианскими дополнениями к Фрейду параноидно-шизоидная позиция соответствует самому раннему этапу психического становления и относится к первым шести месяцам жизни младенца. Поэтому психическая эволюция Делёза и Гваттари, проходя через Эдипа, как бы совершает затем разворот и возвращается к своему истоку - желающим машинам, но уже на другом уровне сознания. Или, если не повезет, срывается на этот уровень, утрачивая все достижения эдипальной фазы.

22 Об этом см.: Делёз Ж. Логика смысла. М., 1995. С. 224.

23 Deleuze G. Guttari F. Capitalisme et schizophrénie 1. L'AntiOedipe. Paris, 1972. P. 148. 


\section{Психология и психотехника 5(56) • 2013}

То есть мы можем эксплицировать из «Анти-Эдипа» следующую мысль. Существует два типа психоза: управляемый, являющийся результатом выхода сознания на следующий этап психической эволюции, и подлинный, наступающий, когда субъект не справляется с нагрузкой, необходимой для этого этапа развития, и срывается, регрессирует на предыдущую ступень. Такое понимание психоза аналогично фрейдовскому пониманию невроза с той лишь разницей, что Фрейд считал психическое развитие человека законченным, если он благополучно прошел эдипову фазу. Эволюция Фрейда заканчивается на адаптации к семейным отношениям, то есть, семья оказывается у него своего рода венцом человеческих отношений, предельно сложной структурой. Однако мы все понимаем, что это не так. Над семьей есть по крайней мере еще одна более сложная структура - общество. И, освоившись в семье, индивид вынужден предпринять следующий рискованный шаг - вписаться в социум, что влечет очередную перестройку мировоззрения и психики. Если этот шаг не удается, если возникший социальный конфликт не получается разрешить самостоятельно, возникает невроз или пограничное состояние. Но и на этом история не заканчивается. То, о чем нам говорят в «Анти-Эдипе» Делёз и Гваттари, (но об этом также пишет и Лэинг, а еще раньше конечно Юнг), - что развитие не заканчивается и с освоением социума. Что на завершающем этапе жизни человек должен вписать себя в Универсум. А это означает прояснить свои взаимоотношения с Богом в том или ином его понимании. И вот тогда индивид либо выходит на максимум интенсивности циркулирующих в машине его души либидозных энергий, либо не выдерживает и срывается, и иногда с такой силой, что проскакивает предшествующие социальную и семейную (эдипову) фазы, приземляясь либо в паранойе, в которой сознание и личность в целом присутствуют, хоть и повреждены, либо еще ниже - в шизофрении, за которой может наступить полный распад личности. Поэтому прав был Юнг когда сказал, что молодым, решающим проблемы любви и семьи, показан метод Фрейда, людям постарше, решающим проблемы социальной интеграции - метод Адлера, а зрелым и старым, перед которыми стоят проблемы Идеала - метод самого Юнга.

Так, совершенно неожиданно, являющаяся оплотом позитивного знания эволюционная теория в ее применении к развитию человеческой души подводит нас к проблемам духовного развития и веры.

\section{Список литературь:}

1. Гаррабе Ж. История шизофрении. М.; СПб., 2000.

2. Делёз Ж. Логика смысла. М., 1995.

3. Каннабих Ю. История психиатрии. М., 2002.

4. Кудрявцев П.С. Курс истории физики. М., 1982.

5. Фуко М. История безумия в классическую эпоху. СПб., 1997.

6. Фуко М. Психическая болезнь и личность / Пер. О.А. Власовой. СПб., 2010.

7. Юнг К., Об энергетике души. М., 2010.

8. Deleuze G., Guttari F. Capitalisme et schizophrénie 1. L’Anti-Oedipe. Paris, 1972.

9. Ey H. Des Idees de Jackson a un model organo-dynamique en psychiatrie. Paris: Monterrey, 1997.

10. Hughlings Jackson J. Evolution and dissolution of the nervous system. Croonian Lectures delivered at the Royal College of Physicians, March 1884. Lancet 1884.

\section{References (transliteration):}

1. Garrabe Zh. Istoriya shizofrenii. M.; SPb., 2000.

11. Delez Zh. Logika smysla. M., 1995.

12. Kannabih Yu. Istoriya psihiatrii. M., 2002.

13. Kudryavcev P.S. Kurs istorii fiziki. M., 1982.

1. Fuko M. Istoriya bezumiya v klassicheskuyu epohu. SPb., 1997.

2. Fuko M. Psihicheskaya bolezn' i lichnost' / Per. O.A. Vlasovoy. SPb., 2010.

3. Yung K., Ob energetike dushi. M., 2010.

4. Deleuze G., Guttari F. Capitalisme et schizophrénie 1. L’Anti-Oedipe. Paris, 1972.

5. Ey H. Des Idees de Jackson a un model organo-dynamique en psychiatrie. Paris: Monterrey, 1997.

6. Hughlings Jackson J. Evolution and dissolution of the nervous system. Croonian Lectures delivered at the Royal College of Physicians, March 1884. Lancet 1884. 